256-268 J. Nat. Hist. Mus. Vol. 30, 2016-18

\title{
Secondary succession and soil nutrient dynamics in abandoned fallows of goth in Panchase, central midhill, Nepal
}

\author{
Hom Nath Pathak ${ }^{1} \bowtie$ and Dinesh Raj Bhuju ${ }^{2}$ \\ ${ }^{1}$ Prithvi Narayan Campus, Tribhuvan University, Pokhara, Nepal \\ ${ }^{2}$ Nepal Academy of Science and Technology, Lalitpur, Nepal \\ homnpathak@gmail.com
}

\begin{abstract}
Livestock farming in Nepal have a common feature of temporary shelter called goth. In recent years, young people in the villages go for foreign jobs and there is severe lack of labour force and theGothpractice has gradually been abandoned. In the abandoned gothfallows, plant succession is observed. In Panchase, abandoned fallows of one year, two years, five years, 15 years were sampled. The sampling included species-wise count of plants and their coverage. Density, frequency and coverage were determined to obtain species diversity. Soil samples were taken from each of the fallow studied. It was found that the species diversity increased with the age of the fallow land, whilebeta diversity decreased with the successive fallow age. Soil samples were analyzed forpH value, organic matter, water holding capacity, nitrogen,phosphorusand potassium value. Aluminum and phosphorus were the determinants in succession of herbs by shrubs and then by tree species to climax.
\end{abstract}

Keywords: abandoned fallow, beta diversity, goth practice, soil-nutrient status, species richness

\section{INTRODUCTION}

Directional and cumulative change of vegetation in a community till the climax community is called succession. Succession may be the primary if the community change occurs in the previously non vegetated area. However, secondary succession occurs in once vegetated area after the disturbance due to climatic, environmental or anthropogenic causes (Pathak, 2015). Agricultural abandonment is a global phenomenon, which may be short-term or permanent depending upon the factors driving the abandonment (Nakano, 1992). Trends in globalization and market liberalization have profound effects on agricultural sectors worldwide. The trend of agriculture abandonment is increasingly observed in Nepal. It was reported that there is abandonment of $46.6 \%$ of agricultural land in northeast of Pokhara in 2004 mainly due to urban migration (Khanal \& Watanabe, 2006). In China and Kenya, many rural folk migrated to the cities due to availability of new economic opportunities and better lifestyle, leading to abandonment of many agricultural areas that subsequently led to increase in the net forest cover (Wang et al., 2012; Conelly, 1994).

About one third of Nepal's economy is from the activities in the agricultural sector (NPC, 2014). 
The livestock farming contribute significantly. One common feature of livestock farming in midhill Nepal is the goth system. The goth is shelter or hut made of tree foliage and branches in the upland area especially in vicinity of the forests where the buffaloes, sometimes cows and oxen are left for grazing. Gothalas, the local shepherds, look after these cattle and use the goths as temporary shelters for themselves. In the past, such Goth practices were most common in Panchase area in western mid-hills of Nepal (MDO, 2006). As many young people of Nepal are leaving for foreign employment, the agriculture including goth practices are in stake. The families left in the villages, women, children or old people are either unable to look after the farms or uninterested in these labour intensive works. In Panchase forest area, a good number of goths can be seen near Aaldanda and Bhanjyang of Bhadaure-Tamagi village, but mostly collapsed in recent years. The spaces around these goths are under natural recovery or secondary succession.

The rate of species colonizationand composition is affected by soil, climate, seed bank in the soil and initial level of occurrence of perennial plants (Stolcova, 2002). The re-vegetation of abandoned farmland significantly influences soil organic carbon (SOC) and total nitrogen (TN) (Deng et al., 2013). The outcome of the interspecific interactions among old field plants is highly dependent on nitrogen supply rates but fairly independent of initial plant abundances (Tilman, 1987). Thus nitrogen accumulation is more responsible for community replacement during secondary succession than the vegetation abundances. However, it is considered that the process of vegetation replacement after a disturbance will be influenced greatly by the species composition at the time of disturbances and by the type of disturbing agents (Gonzalez-Rivas et al., 2009). The mineral content and $\mathrm{pH}$ also changes with the increasing fallow ages, thus, causing the replacement of the communities by succeeding species of plants. The species richness also varies greatly in different fallows of various ages. The study was carried out to document the pattern of secondary succession in abandoned fallows and to find any change in soil characters according the fallow age.In the abandoned sites, succession takes place leading to secondary forests, which are important in the context of enhancing biodiversity and in many cases have provided refuge to local species of flora and fauna (Emrichet al., 2000; Sayeret al., 2004). It also gains importance in the context of global carbon sequestrations and enhancing the local faunal diversity (Kettle, 2012; Corbin \& Holl, 2012, Rey-Benayas et al., 2010). Secondary forest can also enhance the water sources for downstream agriculture production and the livelihood of farming communities (Mittleman, 2001).

\section{MATERIALS AND METHODS}

\section{Study area}

Panchase has elevation range from $500 \mathrm{~m}$ to $2500 \mathrm{~m}$; the samplings were carried out at the altitudes between 2015 and $2125 \mathrm{~m}$. This location was at $28^{\circ} 13^{\prime} 21.04^{\prime \prime} \mathrm{N}$ in latitude and $83^{\circ} 48^{\prime} 41.4^{\prime \prime} \mathrm{E}$ in longitude. The study site was Bhadaure-Tamagi village settlement of Panchase area, near Pokhara in western mid-hills of Nepal (fig. 1). The ecosystem of Panchase consists of slopes on all directions with forest, grazing pastures and agricultural land with human settlement in the hills around and valley bottom. The valley bottom also contains aquatic and wetland ecosystem represented by marshy and swampy lands by the stream bed. The Panchase area lies in subtropical and temperate 
climatic zones with sufficient altitudinal variations and orographic rainfall pattern. The annual average rainfall recorded in last 25 years (1985-2010) was $473 \mathrm{~mm}$ in premonsoon season, $3336 \mathrm{~mm}$ in the monsoon season, $171 \mathrm{~mm}$ in post monsoon season and $82 \mathrm{~mm}$ in the winter. Similarly, the annual mean temperature ranged between 20$25^{\circ} \mathrm{C}$ (EbA Project, 2013). The samplings were carried out at the altitudes between 2015 and $2125 \mathrm{~m}$.

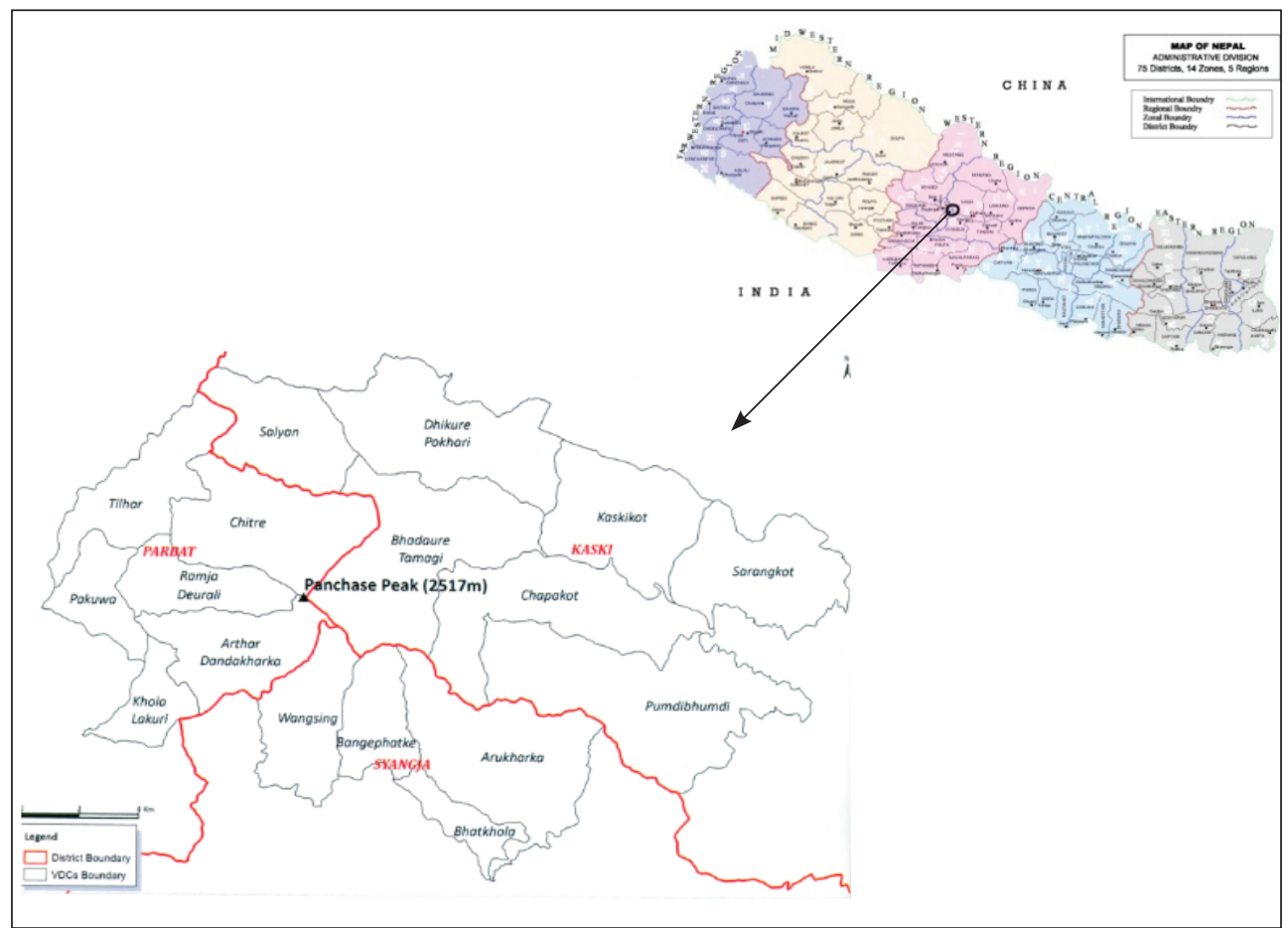

\section{Source: EbA Project, 2013}

Human settlements are situated in the middle to lower part of the Panchase hill. Based on the census of 2011, the estimated population of Panchase area is 62,001 with high discrepancy (4.4:5.6) of male and female (27,406 male and 34,595 female), indicating high out-migration of male population. The forest area nearby the study site was disturbed by grazing by cattle. The distance of the study site from other land use areas is almost two kilometer. The study site was in southfacing slope. The vegetation in the study area is mainly schima-castanopsis type. The other associated tree species are Quercus spp., Rhododendron arboreum, Rhus $\mathrm{sp}$. etc. However the type of forest has been succeededby Daphniphyllum himalayense (EbA Project, 2013).

\section{Reconnaissance of the site}

A preliminary visit of the study area was conducted before data collection to know about the condition of Gothsand also to find out the secondary succession and locate the sites. 


\section{Sampling}

For succession study, the abandoned fallows of goths were identified with the help of local farmers and village heads or the elders. Abandoned fallows of/after 1 year, 2 years, 5 years, 15 years and the old forest were selected as seral stages. In one (fallows abandoned before one year) quadrats of $1 \mathrm{~m} \times 1 \mathrm{~m}$ and in two years quadrats of $2 \mathrm{~m} \times 2 \mathrm{~m}$ were used by random sampling (Ohtsuka et al., 1999). For five years, $5 \mathrm{~m} \times 5 \mathrm{~m}$ quadrats and for 15 years and climax forest, $10 \times 10 \mathrm{~m}$ quadrats were selected at random (Haripal \& Sahoo, 2010). In each of the fallow type any four quadrats were studied making total of 20 quadrats. Plant specimens were collected, the herbarium specimens were confirmed by the villagers and they were identified using standard literatures (Polunin \& Stainton, 1984; Stainton, 1988; Manandhar, 2002).

\section{Data collection}

Vegetation data: density, frequency and coverage of the species were measured following Kent \& Coker (1998). For density, numbers of the particular species were enumerated and for frequency presence or absence of the species in the sampling plots were calculated. Similarly for coverage visual estimation was carried out. The species enumerated in each quadrat were grouped together to determine frequency, density and coverage.

Soil data: soil samples were collected following methods described by Trivedi \& Goel (1984). From each of the vegetation sampling plot about $1 \mathrm{~kg}$ of soil was collected up to the depth of 10 centimeter by making four holes which is collected in polythene bags and mixed homogenously. Each of such bags was sealed tightly. The soil samples were taken for the study of $\mathrm{N}, \mathrm{P}, \mathrm{K}, \mathrm{Al}$, soil $\mathrm{pH}$ and $\mathrm{WHC} \%$, etc. Field visit for data collection was carried during July 15 to August 15, 2014.

\section{Data analysis}

\section{Vegetation analysis}

The vegetation data was analyzed quantitatively for density and frequency using Mishra (1968). Importance value index was calculated by adding the values of relative density, relative frequency and relative cover. Species diversity was calculated by using formula given by Margalef (1968). Beta diversity was calculated by using general formula: $\beta=$ Sc /S (Whittaker, $1975)$, Where, $\beta$ is species turn over, $S c$ is total number of species in all sample units and $S$ is total number of species in a sample unit.Similarly, the floristic similarities among all fallows of various ages were subjected to similarity index from Jaccard's index to find out the similarity between the seral plots.

\section{Soil analysis}

Soil $\mathrm{pH}$, water holding capacity, NPK status and aluminum status were compared and analyzed with the increasing fallow ages of the gothpractices. The soil data were obtained partly in regional soil testing laboratory, Pokhara and partly in the laboratory of LIBIRD, Pokhara. The $\mathrm{pH}$ value, organic matter in percentage, nitrogen percentage, phosphorus in $\mathrm{kg}$ per hectare, potassium in $\mathrm{kg}$ per hectare were obtained from regional soil testing laboratory. Similarly, water holding capacity, percentage, exchangeablealuminum in meq per 100 gram were obtained from soil and plant analysis laboratory (LIBIRD, Pokhara). 


\section{RESULTS AND DISCUSSION}

\section{Floristic composition}

The number of species increased with the increase in the age of fallow; for instance, the mean species number was 25 in one year old fallow, 32 in two years old, 38 in five years old and 40 in 15 years old fallow (fig. 2). The highest value of species richness in 15 years' fallow could be due to presence of all types of herbs, shrubs and trees and absence of strong shade of the trees upon the ground and arboreal vegetation. Species diversity i.e. alpha diversity increased from 1, 2, 5, 15 years fallows but decreased in old forest. However, the community diversity was less in old forest than that of 5 years and 15 years fallows. Pathak (1999) had also the same conclusion and it was the similar observation in both cases of Khoriyafallows then and Goth fallows at present.

Beta diversity or species turn over; the rate of replacement of the plant community by the successive plant community till the climax was decreasing with the increase in fallow age. The highest rate of replacement was observed in one year fallow (6.92), second highest value was at the two years fallows (5.40) and medium was at the five years fallow (4.55) and the old forest (4.55) (fig. 6). The minimum rate of replacement was observed in 15 years fallow community. The decrease in rate of replacement shows that the highest rate of replacement was found in pioneer communities because the herbaceous community changes faster than the shrub species. The minimum rate of replacement in 15 years fallow was probably due to the presence of herbs, shrubs and trees all replace one after another proportionately more than herbs and less than trees in old forest.

In one year fallow, all the plants were herbs. In two years fallow, there were 30 herb species and two shrub species. In five years' fallow community; there appeared two tree species and seven shrub species while all other 29 species were herbs. In 15 years fallow community, 7 tree species were enumerated with 10 shrub species and all other 23 herbs. In old forest 7 tree species, 4 shrub species and all other 27 species were herbs (table1). The trend of replacement of herbs by shrubs and shrubs by trees shows the pattern of secondary succession in abandoned goth fallows.

TABLE 1. Plant species found in abandoned fallows of the goth.

\begin{tabular}{|l|l|l|c|c|c|c|c|}
\hline S.N. & Species & $\begin{array}{l}\text { Life } \\
\text { form }\end{array}$ & 1year & 2 year & 5 year & $\begin{array}{l}\mathbf{1 5} \\
\text { year }\end{array}$ & $\begin{array}{l}\text { Old } \\
\text { forest }\end{array}$ \\
\hline 1. & Achyranthes aspera & Herb & & & + & & \\
\hline 2. & Achyranthes sp. & Herb & + & & & & \\
\hline 3. & Aconogonum molle & Herb & & + & & & \\
\hline 4. & Ageratina adenophora & Herb & & & + & + & + \\
\hline 5. & Allium sp. & Herb & & & & + & \\
\hline 6. & Anaphalis busua & Herb & & + & & & + \\
\hline 7. & Arisaema erubescens & Herb & & & + & + & + \\
\hline 8. & Arisaema turtuosum & Herb & & + & + & + & + \\
\hline 9. & Artemisia sp. & Herb & & & & & + \\
\hline
\end{tabular}


Pathak and Bhuju: Secondary succession and soil nutrient dynamics

\begin{tabular}{|c|c|c|c|c|c|c|c|}
\hline 10. & Artemisia vulgaris & Herb & + & & + & & \\
\hline 11. & Arundinaria sp. & Herb & & & & + & \\
\hline 12. & Berberis aristata & Shrub & & + & + & + & + \\
\hline 13. & Berberis asiatica & Shrub & & & + & & \\
\hline 14. & Brachiaria sp. & Herb & & + & + & & \\
\hline 15. & Carex sp & Herb & + & + & & & + \\
\hline 16. & Cautleya spicata & Herb & & & & + & + \\
\hline 17. & Centella asiatica & Herb & + & + & & & + \\
\hline 18. & Cheilanthes sp. & Herb & & & + & & \\
\hline 19. & Colocasia sp. & Herb & + & & & & \\
\hline 20. & Commelina paludosa & Herb & & & + & & + \\
\hline 21. & Commelina sp. & Herb & & + & + & & + \\
\hline 22. & Cynodon dactylon & Herb & + & + & + & & \\
\hline 23. & Cynotis sp. & Herb & & & + & & \\
\hline 24. & Rhynchospora colorata & Herb & + & + & + & + & \\
\hline 25. & Cyperus sp. & Herb & + & + & + & + & \\
\hline 26. & Daphne sp. & Shrub & & & + & + & \\
\hline 27. & $\begin{array}{l}\text { Daphniphyllum } \\
\text { himalayense }\end{array}$ & Tree & & & + & + & + \\
\hline 28. & Desmodium sp. & Tree & & & & & + \\
\hline 29. & Digitaria sp. & Herb & + & + & & & + \\
\hline 30. & Drymaria sp. & Herb & & & + & + & + \\
\hline 31. & Dryopteris sp. & Herb & + & & + & + & + \\
\hline 32. & Eurya acuminata & Tree & & & & + & \\
\hline 33. & Eurya cerasifolia & Tree & & & & + & \\
\hline 34. & Galium sp. & Herb & + & + & + & + & + \\
\hline 35. & Habenaria sp. & Herb & & + & & & \\
\hline 36. & Hedera nepalensis & Herb & & & & + & + \\
\hline 37. & $\begin{array}{l}\text { Hemiphragma } \\
\text { heterophyllum }\end{array}$ & Herb & + & + & + & & + \\
\hline 38. & Homalium nepalense & tree & & & + & + & \\
\hline 39. & Hypericum podocarpoides & Herb & & + & & & \\
\hline 40. & Hypericum sp. & Herb & & + & + & + & + \\
\hline 41. & Imperata cylindrica & Herb & & + & & & \\
\hline 42. & Imperata sp. & Herb & & + & + & & + \\
\hline 43. & Lycopodium sp. & Herb & & + & + & + & \\
\hline 44. & Macaranga sp. & Tree & & & & & + \\
\hline 45. & Maesa chisia & Shrub & & & + & + & + \\
\hline 46. & Melastoma normale & Tree & & & & + & + \\
\hline 47. & Melochia sp. & Herb & + & + & + & + & + \\
\hline
\end{tabular}




\begin{tabular}{|c|c|c|c|c|c|c|c|}
\hline 48. & Funaria sp. & Herb & + & + & + & & + \\
\hline 49. & Ophiorrhiza sp. & Herb & + & & & & \\
\hline 50. & Osbeckia stellata & Shrub & & & + & & \\
\hline 51. & Oxalis sp. & Herb & + & + & + & & \\
\hline 52. & Pilea scripta & Herb & + & + & + & + & + \\
\hline 53. & Piptanthus sp. & Shrub & & & & + & \\
\hline 54. & Plantago major & Herb & & + & & & \\
\hline 55. & Polygonum sp. & Herb & + & & + & & \\
\hline 56. & Potentilla lineata & Herb & & + & & & \\
\hline 57. & Potentilla sp. & Herb & & & & & + \\
\hline 58. & Pouzolziasp. & Herb & + & + & & & + \\
\hline 59. & Pteridium aquilinum & Herb & & & + & & \\
\hline 60. & Pyracantha crenulata & Shrub & & & & + & + \\
\hline 61. & Quercus sp. & Tree & & & & & + \\
\hline 62. & Ranunculus sp. & Herb & & & + & & \\
\hline 63. & Rhododendron sp. & Tree & & & & + & + \\
\hline 64. & Rhus sp. & Tree & & & & + & + \\
\hline 65. & Rhus wallichii & Tree & & & & & + \\
\hline 66. & Rubus acuminatus & Shrub & & & & + & \\
\hline 67. & Rubus ellipticus & Shrub & & + & + & + & \\
\hline 68. & Rubus gothicus & Shrub & & & + & + & \\
\hline 69. & Saccharum sp. & Herb & + & + & & & \\
\hline 70. & Saccharum spontaneum & Herb & + & + & & & + \\
\hline 71. & Selaginella sp. & Herb & + & & + & + & + \\
\hline 72. & Smilax aspera & Shrub & & & & + & \\
\hline 73. & Smilax sp. & Shrub & & & & + & \\
\hline 74. & Solena heterophylla & Herb & & & & + & \\
\hline 75. & Stellaria sp. & Herb & + & + & & & \\
\hline 76. & Swertia chiraiyta & Herb & & & + & + & + \\
\hline 77. & Swertia sp. & Herb & + & + & & & \\
\hline 78. & Symplocos ramosissima & Tree & & & & + & \\
\hline 79. & Taraxacum parvulum & Herb & & & & + & + \\
\hline 80. & Viburnum mullah & Shrub & & & & + & \\
\hline 81. & Viola sp. & Herb & + & & & + & \\
\hline
\end{tabular}

Similarly, there appeared more differences between the fallows of five years and old forest. According to the similarity index first year and 15 years' fallow communities were most similar (7.125) (fig. 1). Two and 15 years' fallows were also similar next (4.142). Similarly, five and 15 years' fallows were also almost similar (3.588). It means 15 years' fallows have common similar species with one or five years' fallow communities. One year fallow was similar with five years' fallow and old forest. Mostly the herb species in one year fallow community were also found in five years fallow and old forest. The similarity between 15 years' fallows and old forest 
indicated that there were common tree and shrub species in these two fallow communities. Least similarities appear between two and five years and five years' fallow with old forest.

\section{Pattern of secondary succession in abandoned fallows of goth system}

Budowski (1970) classified seral stages of secondary succession into pioneer communities, secondary communities and climax communities. One year and two years' fallow communities represent the pioneer communities. In the study area, there were herb species that occupied the denuded area for goth practice. Those herb species included Drymaria sp., Polygonum spp., Centella asiatica, Pilea scripta, Pouzolzia sp. etc (table 1). Those early succession species reproduce locally and invade recent openings (Horn, 1974). It is represented by five and 15 years' fallow communities. Here the herb species were replaced by the shrub species. However, there were herb species underneath those shrubs. Tree species were appeared rarely in late secondary stages. Shrubs were abundant but were few species. Important species of this stage were Artemisia sp., Galium sp., Maesa chisia, Eurya acuminata, E.cerasifolia, Rhus sp. etc. Similar representative species were also observed by Pathak (1999) in a study of secondary succession in Khoriya fallows.

There was least distinction between late secondary stages of fallow ages 20-30 years and old forest or climax forest (Budowski, 1970). There were few species of shrubs with many individuals. Herbaceous ground vegetation with many species but with few individuals. Dominant tree specieswere Daphniphyllum himalayense, Quercus glauca, Rhododendron arboreum, Rhus sp., etc.

TABLE 2. Arboreal characters of the seral communities (modified after Budowski, 1970)

\begin{tabular}{|c|c|c|c|c|}
\hline S.N. & & $\begin{array}{c}\text { Pioneer } \\
\text { communities }\end{array}$ & $\begin{array}{l}\text { Secondary } \\
\text { communities }\end{array}$ & Climax community \\
\hline 1. & Indicator fallows & $1 \mathrm{yr}, 2 \mathrm{yrs}$ & 5 yrs, 15 yrs & Old forest \\
\hline 2. & Major species & $\begin{array}{l}\text { Drymaria, Polygonum, } \\
\text { Centella, Pilea, } \\
\text { Pouzalziaetc. }\end{array}$ & $\begin{array}{l}\text { Maesa chisia, } \\
\text { Smilax, Eurya, } \\
\text { Pyracantha etc }\end{array}$ & $\begin{array}{l}\text { Daphniphyllum, } \\
\text { Quercus, Osbeckia, } \\
\text { Berberis etc }\end{array}$ \\
\hline 3. & Number of strata & One very dense & $\begin{array}{l}\text { Two well } \\
\text { differentiated } \\
\text { rarely three } \\
\end{array}$ & $\begin{array}{l}\text { Three or four to five, } \\
\text { difficult to discern. }\end{array}$ \\
\hline 4. & Growth & Very fast & $\begin{array}{l}\text { Very fast, trees } \\
\text { slow }\end{array}$ & Slow or very slow \\
\hline 5. & Stem & Soft, herbaceous & $\begin{array}{l}\text { Soft or hard, } \\
\text { lighter }\end{array}$ & Hard and heavy \\
\hline 6. & Shrubs & $\begin{array}{l}\text { No shrubs } \\
\text { encountered }\end{array}$ & Few species & $\begin{array}{l}\text { Few in number but } \\
\text { many }\end{array}$ \\
\hline 7. & Epiphytes & Absent & Very few & $\begin{array}{l}\text { Few in number but } \\
\text { many species }\end{array}$ \\
\hline 8. & $\begin{array}{l}\text { Tolerance of } \\
\text { dominance to } \\
\text { shade }\end{array}$ & Intolerant & $\begin{array}{l}\text { Tolerant at } \\
\text { juvenile but } \\
\text { intolerant }\end{array}$ & Tolerant except adult \\
\hline
\end{tabular}




\section{Soil plant relationships}

Soil in the study area was slightly acidic in nature (fig. 3). It showed that the acidity was higher in 1st year fallow than in 2nd year fallow soil. Then acidity goes on decreasing but in 15 years fallow it was slightly greater. Therefore, $\mathrm{pH}$ showed no definite pattern with the fallow ages. However, the soil in five years' fallow was more acidic.Least $\mathrm{pH}$ value was observed in 15 years' fallow. It was similar to the result obtained by Paudyal (1996). Decreasing value of pH, nitrogen as well as organic matter was similar with the result obtained by Liu and Huang (2005). The decreasing trend of $\mathrm{pH}$ (as shown in 2nd, 5th and 15th years' fallow) was also obtained by a study carried out in China (Li et al., 2013).

How the organic matter (OM) decreased with the increase in fallow age in the abandoned fallows of the goth system is shown in fig. 6 . The highest value of the organic matter was observed in 1st year fallows. Addition of the dung by the goth practitioners may be the cause behind it. The lowest value was in old forest $(4.69 \%)$. The OM percentage was found lower in five years' fallows too $(5.75 \%)$. The organic matter was also consumed by the increase in complexity of herbs, shrubs to tree direction. Although the organic matter was observed with increased fallow ages in abandoned fallows in slash-and-burn (Paudyal, 1996), the study by Liu \& Huang (2005) observed a decreasing trend of OM in successive seral communities.

Nitrogen value in first, second and 15 years' fallows had the exactly same value of $0.33 \%$ (fig. 4). The old forest contained the highest value $(0.46 \%)$. Nitrogen percentage in soil appeared same in one year, two years', five years' and 15 years' fallow communities but was found highest in old forest. Thus nitrogen in soil seems increasing after five years fallow. Paudyal (1996) also concluded the same that there was less value of nitrogen in five years fallows. In a study in abandoned farmland in Loess Plateau, China, Deng et al. (2013) found that the soil OC and N storage was significantly lower in the younger grasslands ( $<20 \mathrm{yr}$ ), had increased in the older grasslands (30 yr), and at 30 years SOC had increased to pre-abandonment levels.

Phosphorus value showed no definite pattern with the fallow age (fig. 5). The highest value was at the fallows of five years (150 kg/ha). In 15 years' fallows, there was least value of the phosphorus (38 kg/ ha). In old forest there was lower value of phosphorus than the value at first year's soil. Phosphorus compound was most stable compound than other nutrients (Wild, 1998). Phosphorus in the form of phosphorus pentoxide seems very low in all soil samples. It did not show any definite pattern with the fallow ages. The highest value of phosphorus in five years fallow resembles the result of Paudyal (1996). The lowest phosphorus was observed there in 15 years fallows.

Amount of potassium appeared highest in one year fallow (fig. 5). It slightly decreased in two and five years. It had medium values in 15 years' and old fallows of Goth system. High potassium value in first year fallow was due to the fallow being recently abandoned after cultivation. Least value in two years' fallow and five years' fallow was due to used up fertilizers and least values of nitrogen and organic matter. Second highest value in old forest was probably due to availability of decomposed litter in old forest.

Exchangeable aluminum goes on increasing from first year's fallow (3.175meq/100gm), second years' fallow (4.082 meq/100 gm), decreased in five years' fallow (2.722 meq/100 gm) and again increased in 15 years' fallow (4.687 meq/100 gm) (fig. 3). Aluminum was found lowest at the old forest (fig.3). 
The decrease in $\mathrm{pH}$ value with increase in fallow age favored the high solubility of aluminum that increased in successive fallows. Thus,aluminum became toxic aluminum hydroxide to herb species. It is because toxic effect of aluminum hydroxide reduced the uptake of cations like $\mathrm{K}, \mathrm{P}$ etc. Therefore they are replaced by shrub species or more woody, tolerant and deep rooted species. This result here gets support of the study by Black (1968). In other cases where there is high phosphorus value, the aluminum toxicity is reduced by accumulation of phosphorus.

The water holding capacity (WHC) of first year fallow was $43.36 \%$ (fig. 5). It went on increasing in which second years' fallow contained $50.21 \%$, five years' fallow $57.96 \%$. But the value decreased in old forest with $49.20 \%$. This value was greater than that of the first year's fallow community. Higher organic matter (OM) value was found in fallows of pioneer types and it went on decreasing in successive fallows. Greater the OM value greater the WHC per cent by the rule. But in this case, organic matter was greater in first years' fallow. Similar value was in second and 15 years' fallow but in five years' and old forest it had lowest value. In five years' fallow and old forest, the organic matter also was medium or decreased. The highest value of WHC in 15 years' fallow in spite of the lowest organic matter is probably governed by the texture and increased in microflora of bacterial to fungal type.

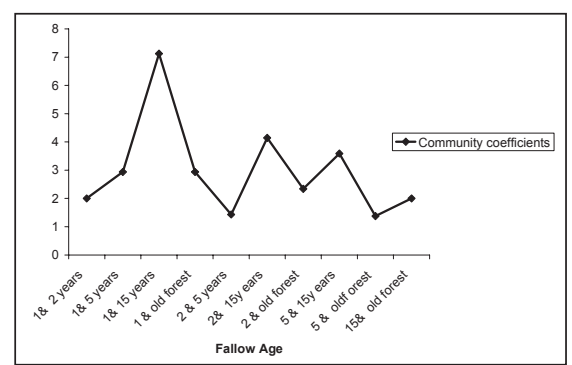

FIG. 1. Fallow age and similarity index.

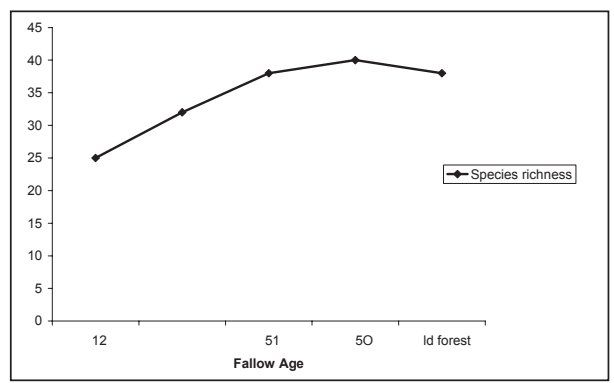

FIG. 2.Fallow age and species richness.

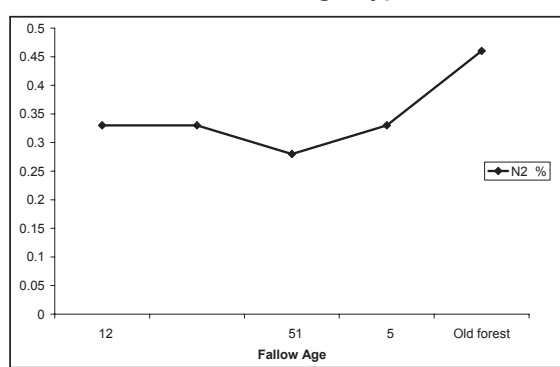

FIG. 4. Fallow age and nitrogen.

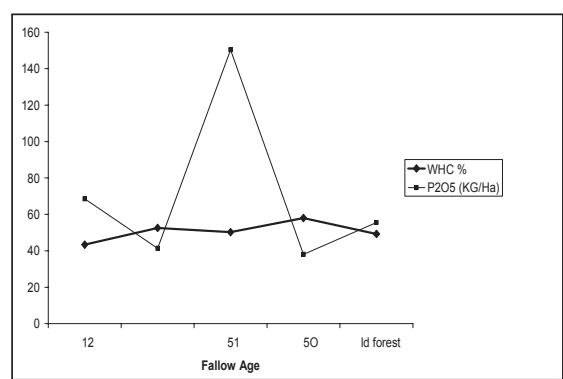

FIG. 5. Fallow age, water holding capacity and phosphorus. 


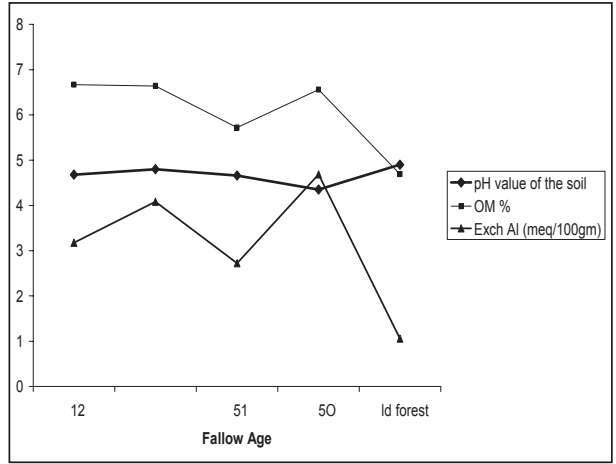

FIG. 3. Fallow age, $\mathrm{pH}, \mathrm{OM}$ and $\mathrm{Al}$.

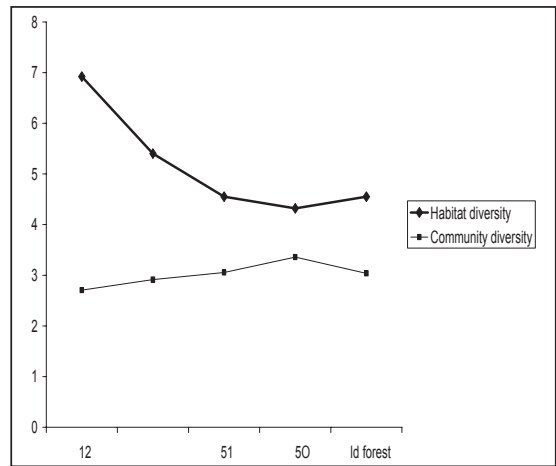

FIG. 6. Fallow age, habitat diversity and community diversity.

Abandoned goth fallows and their ages were identified from the Gothalas in the Goths. The first, second, fifth, fifteen and old forest communities were sampled and quadrats of $1 \mathrm{~m} \times 1 \mathrm{~m}, 2 \mathrm{~m} \times 2 \mathrm{~m}, 5 \mathrm{~m} \times 5 \mathrm{~m}$, and $10 \mathrm{~m} \times 10 \mathrm{~m}$ were laid down in $1^{\text {st }}, 2^{\text {nd }}, 5^{\text {th }}, 15^{\text {th }}$ and old forests. Species of herbs, shrubs and trees were enumerated for frequency, density, and coverage. These data were manipulated to obtain importance value index by which species diversity, habitat diversity (species turn over) were obtained. Similarity index was calculated to relate different fallows. Finally the pattern of secondary succession was traced out.The species diversity was found increasing with the increase in fallow ages but found decreasing to old forest. The rate of species replacement was obtained highest in first year fallow but went on decreasing with increase in fallow age.

Soil samples were collected from every fallow sampled. Soil samples were tested for $\mathrm{pH}$, $\mathrm{WHC}, \mathrm{N}, \mathrm{P}, \mathrm{K}, \mathrm{OM}$, and $\mathrm{Al}$ and their trend of those nutrients with the increasing fallow ages. The $\mathrm{pH}$ value decreased with the fallow age, the organic matter also decreased with the increase in fallow age. Nitrogen value was random in the fallow age. Phosphorus did not show any definite pattern. Potassium value appeared highest in first year fallow after abandonment and can be said that it is decreasing.

The present research findings highlight how the secondary forestsare formed and what the relations are there between soil nutritionand fallows age. The abandonment of goth system in the mid-hills ofNepal has brought back species richness and greenery. This supports the concept of secondary succession.

\section{ACKNOWLEDGEMENTS}

The study was undertaken with the grant support of Ministry of Science, Technology and Environment facilitated by Institute of Science and Technology, Tribhuvan University. The soil test was carried out at Western Regional Soil Testing Laboratory and LIBIRD, Pokhara.

\section{REFERENCES}

BLACK, C A (1968) Soil plant relationship, Willy Eastern, New Delhi, India (2nd ed).

BUDOWSKI, G (1970) The distinction between old secondary and climax species in tropical central 
American lowland forests. Tropical Ecology1: 1-32.

CONELLY, W T (1994) Population pressure, labor availability, and agricultural disintensification: The decline of farming on Rusinga Island, Kenya. Human Ecology 22: 145-170.

CORBIN, J D; HOLL, K D (2012) Applied nucleation as a forest restoration strategy. Forest Ecology and Management 265: 37-46.

DENG, L; SHANGGUAN, Z-P; SWEENEY, S (2013) Changes in soil carbon and nitrogen following land abandonment of farmland on the Loess Plateau, China. PLoS ONE 8(8): e71923. https://doi.org/10.1371/ journal.pone.0071923.

EBA PROJECT(2013) Ecosystems and ecosystem services of Panchase: an overview. Based on baseline and socio-economic survey conducted by EbA, Project, Babarmahal, Kathmandu, Nepal.

EMRICH, A; POKORNY, B; SEPP; C (2000) The significance of secondary forestmanagement for development policy. TOB Series No. FTWF-18e.GTZ.

GONZALEZ-RIVAS, B; TIGABU, M; CASTRO-MARIN, G; ODOM, P C (2009) Soil seed bank assembly following secondary succession on abandoned agricultural fields in Nicaragua. Journal of Forestry Research 20(4) :349-354.

HARIPAL, K; SAHOO, S (2010) Vegetational dynamics in some tropical abandoned rice fields in the western part of Orissa, India. African Journal of Environmental Science and Technology 5(1): 37-44, http://www.academicjournals.org/AJEST.

HORN, H S (1974) The ecology of secondary succession. Annual Review of Ecology and Systematic 51: 25-37.

KENT, M;COKER, P (1998)Vegetation description and analysis: a practical approach.John Willey and Sons,Chischetor, NewYork, USA.

KETTLE, C J(2012) Seeding ecological restoration of tropical forests: priority setting under REDD+. Biological Conservation 154: 34-41.

KHANAL, N R; WATANABE, T (2006) Abandonment of agricultural land and its consequences: a case study in the Sikles area, Gandaki basin, Nepal Himalaya. Mountain Research and Development 26: $32-40$.

LI, Y ; YANG, F ; OU, Y ; ZHANG, D ; LIU ZHANG, Y ; OTIENO, D ;ZHOU, G (2013) Changes in forest soil properties in different successional stages in lower tropical China. PLoS ONE8(11): e81359. doi:10.1371/journal.pone.0081359.

LIU, H; HUANG, J (2005) Dynamics of soil properties under secondary succession forest communities in Mount Jinyun. Ying Yong Sheng Tai XueBao16(11): 2041-6.

NPC (2014)Thirteenth Plan (2013/14-2016/17) National Planning Commission (NPC), Government of Nepal, Kathmandu.

MANANDHAR, N P (2002) Plants and people of Nepal.Timber Press.Portland, Oregan, USA.

MARGALEF, R (1968)Perspectives in ecological theories. University of Chikago Press, Chicago, USA.

MDO (2006) Bulletin.Machhapuchhre Development Organization (MDO), Pokhara, Nepal.

MISHRA, R (1968)Ecology workbook. Oxford and IBH Publishing Company,Oxford, UK.

MITTELMAN, A (2001)Secondary forests in the lower Mekong subregion: an overview of their extent, roles and importance. Journal of Tropical Forest Science13: 671-690. 
NAKANO, K (1992) On the vegetational change in fallows at a hamlet in a north eastern region of Lalaita Island, Solomon Island. South Pacific Study 17:1-20.

OHTSUKA, T; SAKURA, T; OHSAWA, M (1993) Early herbaceous succession along a topographical gradient on forest clear-felling sites in mountainous terrain, Central Japan. Ecological Research 8:329340.

PATHAK, H N (1999)Vegetation succession and impacts of socio-economic factors on Khoriya cultivation, (an ecological study at Lwang/GhaleIVDC, ACAP). M.Sc.Thesis,Central Department of Botany, TribbuvanUniversity, Kirtipur, Kathmandu, Nepal.

PATHAK, H N (2015) Secondary succession in abandoned crop fallows: a review.International Journal of Environment 4(3): 166-176.

PAUDYAL, D P (1996)Nutrient dynamics in secondary successive Khoriya fallows and its management in Lwang/Ghalel and Rivan VDC (Kaski ACAP). M.Sc.Thesis, Central Department of Botany, Tribhuvan University, Kirtipur, Kathmandu, Nepal.

POLLUNIN, O; STAINTON, A (1984) Flowers of Himalaya. Oxford Press, New Delhi, India.

SAYER, J; CHOKKALINGAM. U; POULSEN, J (2004) The restoration of forest biodiversity and ecological values. Forest Ecology and Management 201:3-11.

REY-BENAYAS, J M; BULLOCK, J M; NEWTON, A C (2008) Creating woodland islets to reconcile ecological restoration, conservation, and agricultural land use. Frontiers in Ecology and the Environment 6: 329-336.

STAINTON, A (1988) Flowers of the Himalayas- a supplement. Oxford University Press, New Delhi, India.

STOLCOVA, J (2002) Secondary succession on an early abandoned field: vegetation composition and production of biomass. Plant Protection Science 38(4): 0-0. Available at http://www.agriculturejournals. cz/publicFiles/57123.pdf.

TILMAN, D (1987) Secondary succession and the pattern of plant dominance along experimental nitrogen gradients. Ecological Monographs 57(3): 189-214.

TRIVEDI, R K; GOEL, P K (1984)Chemical and biological methods for water pollution studies. KaradEnvironmental Publication, India.

WANG, C ; YANG, Y ; ZHANG, Y (2012) Rural household livelihood change, fuelwood substitution, and hilly ecosystem restoration: Evidence from China. Renewable and Sustainable Energy Reviews 16:24752482.

WHITTAKER,R H (1975) Community and ecosystems. McMillan, New York, USA (2nd ed.).

WILD, A (1988) Plant nutrients in soil: Phosphate. InWILD, A. (ed) Russell's soil condition and plant growth.Longman Group Limited; UK; pp 695-742. 